standards of human needs". The president, Sir Robert Watson-Watt, the hon. general secretary, Dr. W. A. Wooster, and the treasurer, Dr. S. Masterman, were re-elected to hold office for the coming year. The Association has just published the full proceedings of the Conference on "Planning of Science" held during January 30-31.

\section{Aims of the Association}

For his presidential address to the Association, Sir Robert Watson-Watt took as his theme the topic of contentment. The Association, he pointed out, is now strong, but still not fully representative of scientific and technical workers as a whole. Nevertheless, it is strong enough to be able to admit misunderstanding of its objects. One charge brought against the Association is that it is more concerned with politics than science; this suggests that some people do not realize how fundamental politics is. Scientific workers are citizens, and as such they should be profoundly concerned with the application of science to the good of the State and of the world. Politics means publicity, and so the Association must of necessity undertake to influence public opinion. The social relations of science is a primary object of study for the Association, but propaganda and economic and engineering efficiency play equal parts in its trade union activities. It has been said the Association fosters enmity between juniors and seniors. Sir Robert takes the view that the enmity already exists, though to a diminishing extent, and he is all for bringing it out into the open and treating it by free discussion. Seniors who make this charge are suffering from the dread disease of contentment. The last charge he discussed was that the Association consists of idealists. To the extent that we all believe in the possibility of making a better world, we are idealists, But Sir Robert was scathing in his comments on dangerous idealists of industrial research laboratories, who declare that the methods of the Association have brought discord between laboratory staff and management; they indeed are suffering from contentment, or even complacency, which may easily come to mean smugness.

\section{Anglo-Czechoslovak Chemical Collaboration}

THE need for closer collaboration between British and Czechoslovak chemists was stressed at a meeting under the auspices of the Association of Czechoslovak Scientists and Technicians Abroad held at the Czechoslovak Institute, Grosvenor Place, London, on May 14. It was attended by Czechoslovak chemists serving or working in Great Britain and by members of the five British chemical societies, and was addrèssed by Dr. G. Druce and by Dr. George Lewi, chairman of the chemical group of the Czechoslovak association. Dr. Druce briefly described some of the contributions of Czechoslovak chemists to the advancement of science, particularly during the two decades between 1918 and 1938 . Reference was also made to the importance attached by Czechoslovak educational authorities to science and scientific research, especially in chemistry. There is a relatively extensive scientific and technical literature, and Czechoslovakia possessed many public and corporate research institutes in connexion with the country's sugar, glass, brewing, mining and metallurgical industries and with agriculture and forestry. The German occupation of Czechoslovakia and the closing of the universities, etc., has interrupted the investi- gations in progress under Crechoslovak men of science, but with such a tradition as they possess, the nation's chemists and technologists will doubtless resume and extend their peaceful activities as soon as the country regains its independence. In this work British chemists will wateh with interest the efforts to reconstruct the chemical and other scientific institutions and the industries they serve.

Dr. Lewi gave an impressive account of his country's chemical industry, the extent of which has not been realized abroad. The output was very great and included a long list of varied types of products. Nevertheless, Czechoslovakia imported considerable quantities of chemicals and similar products. Hitherto these had come mainly from Germany. Again, although Czechoslovakia's natural resources are great and include most metal ores as well as coal, lignite, graphite and pitchblende and also timber, they were insuificient for local needs and more had to be imported. In particular, the chemical and allied industries would need financial and technical assistance for the reconstruction that would take place in the post-war years. This help could best come from British sources, to which Czechoslovak chemists look for guidance in the dificult times ahead. Many industries would be left in ruins by the Germans, who had already pillaged both private industrial undertakings and public scientific institutions. Dr. Lewi took the opportunity to agree with Sir Robert Robinson's contention that the German chemical industry must not be allowed to menace mankind in the future. In the meanwhile, the Czechoslovak chemical community in Britain plases its knowledge and experience at the disposal of the common cause, and at the same time attempts to assist its members and student nationals to prepare for the tasks that lie before them when they return to their liberated homeland.

\section{Reconstruction in the Birmingham Area}

SPEAKING to the Birmingham General Branch of the Association of Scientific Workers on June 1 on "Reconstruction in Birmingham and the West Midlands", Councillor Paul Cadbury outlined the original research work which is being done by a group of paid and voluntary workers connected with the University of Birmingham under the chairmanship of Dr. R. E. Priestley and the technical direction of C. B. Parkes of the Bournville Village Trust. Surveying the five counties forming the Midland Civil Defence Region, by excluding land of various categories (for example, inaccessible, marshy, highly fertile, and of great natural beauty) there remains only a very restricted number of areas suitable for future industrial and urban development. In some cases these happen to adjoin existing market towns (for example, Bridgnorth) which have facilities and services particularly suitable for an increased population. Before the publication of the Uthwatt Report, Mr. Cadbury said that State ownership of all land was recommended as ideal, with the vesting in the State of the development rights of all land as an immediate necessity. In rebuilding, existing towns should be broken down where possible into 'neighbourhood units', each with its own community centre and group of industries. Large dormitory suburbs and dependence on only one industry would thus be avoided. The whole talk provided an excellent example of realistic application of the scientific method of planning to a social problem. 